\title{
An Analysis on Locating and Finding the Most Appropriate Option in Order to Shifting Capital in Iran
}

\author{
Masoud Taghvaei ${ }^{1}$, Neda Rahmani ${ }^{2} \&$ Mahsa Akrami $^{3}$ \\ ${ }^{1}$ Professor of geography and urban planning, University of Isfahan, Isfahan, Iran \\ ${ }^{2}$ MA of geography and urban planning, University of Isfahan, Isfahan, Iran \\ ${ }^{3}$ MA of geography and urban planning, University of Isfahan, Isfahan, Iran \\ Correspondence: Masoud Taghvaei, Professor of geography and urban planning, University of Isfahan, Isfahan, \\ Iran. E-mail: m.taghvaei@geo.ui.ac.ir
}

Received: February 12, 2016

Accepted: March 22, 2016

Online Published: May 17, 2016

doi:10.5539/mas.v10n8p18

URL: http://dx.doi.org/10.5539/mas.v10n8p18

We are grateful to Center of excellence; Geography and urban and regional planning to their material and spiritual support in publishing this paper.

\begin{abstract}
Capital is the most important city in every country and it is the concentration center of political, social and economical powers. Every country is introduced by its capital. The issue of shifting capital is offered and conducted in some countries in the world. Iran had the experience of shifting its capital many times in different historical periods according to the certain circumstances. In this research, 19 options are examined. Type of the research is descriptive-analytical type and required information are collected in six indicators of environmental conditions, geographical position, locating in less dangerous zones, suitable facilities and infrastructures, cultural and social structures, economical status using documents and questionnaire. The collected data is analyzed using AHP by Expert Choice software. The obtained results indicate that among examined options, Hashtgerd, Doroud Vazena and Pardis are the most appropriate cities with weights 0.075, 0.068, 0.064, and Qom, Khomein and Hamadan are the most inappropriate cities for shifting capital with weights $0.043,0.043$ and 0.032 .
\end{abstract}

Keywords: shifting capital, capital, Tehran, Iran

\section{Introduction}

Capital is the city with the most population and it is the biggest economical and cultural center (Behforouz, 2002: 197). Most importantly, capital is the political center of a country and settlement of heads of three branches (executive, legislative, juridical), their members, all ministries, state-run offices and foreign embassies. Capitals, which had active roles during the history of a nation, have usually obvious merit to other cities by exhibiting historical, cultural and national symbols (Mirheidar, 1994:143). Indeed, this place is the geographical, geometrical or functional center of a geographical space and it absorbs motivational forces in that space, human and framework factors and elements, currents and networks toward itself. On the other hand, it is counted as a central point for distributing phenomena, orders and political actions all over that space (Hafeznia, 2002:282). Capitals have certain importance as the presentation places of social systems' functions. The matter of shifting capital, transferring and locating a new place is a common issue with historical record. In the meanwhile, such as many countries, Iran was not far from this process during past decades and it shifted and transferred its capital in several stages (Nobari, 2009:4). Actually, choice of a place for shifting capital happens when governments consider their present capital as a dysfunctional city and make themselves leave that capital (Ahmadipour et al., 2011:86). In the process of transferring and locating capitals of Iran, so many factors such as local source, situation of central (main) location and external treats played essential roles as influential geopolitical facts (Ahmadi \& Vali Gholizadeh, 2007:29).

Scientific and experimental evidences show that nowadays, Tehran city is faced to many serious and increasing damages and forms of these damages are clearly seen in dysfunctional actions of infrastructural and framework equipments, economical and social problems and spreading environmental pollutions. Continuing this trend will 
result in reducing quality of life and related treats to different instabilities in metropolitan of Tehran. Another aspect of these instabilities is complexity and deepness of its consequences and it requires a comprehensive and deep cognition (Islamic Council Parliament, research center, 2012:1).

According to inappropriate situation of Tehran city and its related crises, the subject of transferring capital is offered and the present research is written regarding measure of the most appropriate option in order to transferring the capital. Therefore, after analyzing and evaluating options, recommendations about the most appropriate option for transferring the capital are offered according to properties of each option.

\section{The Research Method}

The research method is a combination of documental, library, descriptive and analytical methods. The statistical community includes 19 mentioned options in order to transferring the capital. The method of collecting descriptive or locating information is conducted by referring to the library, scientific research centers and related organizations, taking notes, questionnaire, interview and using the present statistics. AHP is used to analyzing data, measures were evaluated and weighted using Expert Choice software, and then, options were ranked.

\section{Theoretical Principles, Concepts, Definitions and Methods}

\subsection{Definitions and Concepts}

- The core region: the core regions are called to parts of the land of a government that are superior on other regions due to political dominance, national feelings or economical leadership role (or cultural merit) (Mirheidar, 2002:134).

- Capital: as the political focus of a country, capital is attraction and influence center of a geographical space that includes political, cultural, local, economical, bureaucratic, technical and communicative factors (Hafeznia, 2002:282). Before anything else, capital is the center of political control and a place for political decision-making and the symbolic center of a government (Taylor, 1989:147).

\subsection{Theoretical Principles and Approaches}

\subsubsection{Various Doctrines and Theories}

Since process of urbanization had a high-speed development especially during last decades of twentieth century, great transformations have happened in urbanization and spatial and skeletal development in major urban regions especially capitals of the world. In terms of transferring capital and shifting it, such as Hall (1993), Campbell (2003) classified capitals into six groups and determined their samples.

Table1. Types of capitals in terms of classification and their transfer

\begin{tabular}{ll}
\hline Bogota, Karakas, London, Madrid, Rome, Paris & Old (traditional) capitals \\
\hline Ankara, Astana, Lilongwe & Transferred capitals \\
Abuja, Brasilia, Canberra, Islamabad, New Delhi & New-built capitals \\
Moscow, Ottawa, Washington & Central capitals \\
Amsterdam/ Hague, La Paz/ Sucre, Pretolia/ Bloom Fountain/ Kapetown & Bipartite capitals \\
Jakarta, Tokyo & Archipelago capitals \\
Abuja, Brasilia, Canberra, México city, Washington, New Delhi & Capitals with unique power realm \\
\hline
\end{tabular}

Source: Campbell, S. (2003)

In table 2, there is a list of countries with different structures, which transferred their capitals since 1900 so forth.

Table 2. cases of transferring capital in different countries from 1900 so forth

\begin{tabular}{lllll}
\hline To & From & Year & Country & Row \\
\hline Ankara & Istanbul & $\mathbf{1 9 2 3}$ & Turkey & $\mathbf{1}$ \\
Canberra & Melbourne & $\mathbf{1 9 2 7}$ & Australia & $\mathbf{2}$ \\
Islamabad & Karachi & $\mathbf{1 9 5 9}$ & Pakistan & $\mathbf{3}$ \\
Brasilia & Rio de Janeiro & $\mathbf{1 9 6 0}$ & Brazil & $\mathbf{4}$ \\
Dvdma & Dar es Salaam & $\mathbf{1 9 7 4}$ & Tanzania & $\mathbf{5}$ \\
Yamoussoukro & Abidjan & $\mathbf{1 9 8 3}$ & Ivory Coast & $\mathbf{6}$ \\
Putrajaya & Yamoussoukro & $\mathbf{1 9 9 2}$ & Malaysia & $\mathbf{7}$ \\
\hline
\end{tabular}


Source: Campbell, S. (2003)

\begin{tabular}{lllll}
\hline Berlin & Ben & $\mathbf{1 9 9 9}$ & Germany & $\mathbf{8}$ \\
Akvmvla) astaneh( & Almaty & $\mathbf{2 0 0 5}$ & Kazakhstan & $\mathbf{9}$ \\
\hline
\end{tabular}

According to information in table 1 and 2 and conducted studies, we can mention to following items:

A) Transferring capital is experienced equally in all the evaluated countries with different governmental structure. Transferring political capital cannot be counted as the only way of decentralization and reduction of activity and population loading; because this issue is not only related to location and it is used in bureaucratic, financial and political areas or a combination of them.

B) In all examined countries, transferring the capital is conducted according to their political, social and economical conditions.

C) $11 \%$ such as Germany transferred their capitals due to political reasons, $44.5 \%$ such as Brazil, Pakistan, Turkey and Kazakhstan did it due to defensive reasons, 78\% such as Brazil, Pakistan, Turkey, Kazakhstan, Germany and Malaysia did it due to economical reasons and regional development, $32 \%$ such as Germany and Australia did it due to symbolic reasons. $37 \%$ such as Brazil did it due to environmental reasons or issues related to natural disasters. $22 \%$ such as Pakistan and Australia did it simply due to bureaucratic and governmental needs. In some cases such as Malaysia and Germany, economical considerations played essential roles in transferring capitals.

D) In $85 \%$ of cases, new capitals had no significant effect on old capitals and just slightly reduced development of old capitals and made it moderate.

E)New capitals such as Brasilia, Canberra and Islamabad are mostly concentration centers of political and governmental activities, while other economical, cultural, touristic and business activities are still going on in old capitals.

F) In most studied countries, constructing new capitals was not essentially conducted to improving conditions in old capitals. In other word, constructing new capital is greatly a strategic need in most countries. This need was accessing to global communication network for Malaysia and it was bureaucratic and governmental needs for Australia and Pakistan. However, we should not ignore this fact that despite all cases, political power was accompanied by planned and formed move (Firouzi, Mahramali and Hamkar, 2013:41).

\subsubsection{Roles of Capitals in Forming Identity of Countries}

Undoubtedly, identity of a nation is firstly a matter related to political geography regarding manner of creation and stability of that nation. Therefore, a country is alive and dynamic when it has firstly an independent national character. National identity and character of a nation is formed when its constituting phenomena, namely its special cultural and spiritual institutions are present. In every nation, these institutions were born from a special form of communicating thoughts, tastes, beliefs and social approaches of that nation's people and were rooted in special human-social space of that environment and they guarantee that space's coherence and embrace it. So these institutions are considered as identity of that space (Ahmadipour et al., 2009:6).

\subsubsection{Proponents of Transferring the Capital}

Proponents of transferring capital suggest many reasons for shifting Tehran and we mention to some of their important reasons:

- Possibility of occurring earthquake: Iran is one of earthquake-prone countries and more than 90 percent of its regions are located on earthquake line. Metropolitan of Tehran is not safe from danger of earthquake. Also, according to statistical studies and previous earthquake that are registered in Rey and Tehran areas, averagely, one destructively earthquake has happened in this area each 158 years by possibility of more than 70 percent. That is, return period of Tehran earthquakes is about 150-200 years and since more than 170 years have passed after the last strong earthquake in this area, the possibility of earthquake occurrence in Tehran is strongly high (Mahdavi, 2008:5).

- Air pollution: the newest investigations of World Health Organization (WHO) indicate that Tehran is one of the most polluted cities and capitals of the world; in such a way that every minute breathing in Tehran equals smoking nine cigarettes. The pollution risk of Tehran's air is 38 times of global standards and criticality of this city's air rang the alarm bells for authorities (Mahdavi, 2009:5). 


\subsubsection{Opponents of Transferring the Capital}

Decision about transferring the capital had always reactions and oppositions. Opponents of the plan of transferring the capital believe in following strategies:

-Rebuilding old textures and retrofitting Tehran using new technologies in order to resist against earthquake and being hopeful about possibility of predicting time and location of earthquake occurrence in future according to significant advances of human knowledge

-According to this fact that pollution of Tehran's air is offered as one of factors in transferring the capital and while about 80 percent of air pollution in Tehran is due to vehicles, it is possible to remove a part of problems related to pollution using new technologies and changing and transforming fuel of vehicles. In addition, it is possible to reduce usage of individual vehicles by developing public transportation system including subway and integrated urban management.

-Developing required infrastructures and substrates in order to reaching to pattern of the electronic government

-Continuing decentralization policy according to this fact that despite problem of "base", Tehran has a unique geographical situation

-Reasonable and aware distribution of industries, economical, educational, service and other activities all over the country according to land preparation

-Since Tehran has been the capital in more than 200 years of Iran's history in three Qajar, Pahlavi and Islamic republic governments, it acquired a unique feature. For instance, many common historical accidents and events of Iranians happened in this location. In addition, in terms of texture and population combination, such as a transplanted tree, Tehran is full-view picture of Iran (Small Iran). Iranians outside and inside of the country look at Tehran as a identity location and obvious symbol of geographical features and historical transformations.

-If some people consider possibility of earthquake occurrence as necessity of transferring the capital, it should be stated that: earthquake is a natural happening and many developed countries got along with it, as even 7-richter earthquakes have no human loss anymore. Solution of the developed world for standing against earthquake is using knowledge and technology. Moreover, if this (transferring) solution was supposed to used in a country like Japan, all cities of this country would have been vacuumed and transferred to another position in the world (Hamshahri, 2010:8).

\section{Techniques and Methods}

\subsection{Analytic Hierarchical Process (AHP)}

This method is a mathematical multi-criterion evaluation method in decision-making process (Mohanty et al., 2007:254). It combines qualitative and quantitative criteria with each other (Zhijun et al., 2009:465) and offers a reasonable comparison in order to measuring relative importance of elements in each hierarchical level. Moreover, it offers evaluation of options in the lowest level of hierarchy in order to choosing the best decision among multi criteria (Sipahi \& Timor, 2010:775). This method is mostly used to decision-making in operational and high-risky analyses in order to evaluating alternative plans and in smaller level; it is used to evaluating environmental effects (Sonles, 2003:295). Analytical Hierarchical Process requires paired comparisons among options and these comparisons are conducted in form of paired comparison matrixes based on 9-part spectrum of Sa'ati in AHP technique, which is offered by Professor Sa'ati himself (its Iraqi inventor) (Bagheri Bodaghabadi, 2007:107).

The basis of AHP method is a hierarchical display, which helps to solving complicated problems through simple processes. This action requires that criteria would be dissolved in uniform levels (Mepal et al., 2010:2).

\section{Findings of the research}

\subsection{Determining Score of Options Regarding Being Appropriate for Transferring the Capital in Iran}

Stages of using AHP: The first stage: putting objective, the second stage: choosing examined measures and sub-measures, the third stage: Weighting measures (paired comparison). In order to transferring the capital from Tehran, a option will be chose that is appropriate in terms of essential and important indicators. In order to determining these indicators, a questionnaire was prepared which in there were 6 criteria and 21 sub-criteria. Criteria include environmental condition, geographical location, locating in less risky zones in terms of natural disasters, appropriate infrastructures and facilities, cultural and social structures and economic condition. 12 experts scored the questionnaire of the research, criteria and sub-criteria were evaluated using Analytical Hierarchical Process, and finally after calculation, the final weight for each criterion and sub-criterion is shown 
in table 3:

Table 3. Weights of criteria and sub-criteria

\begin{tabular}{|c|c|c|c|c|}
\hline $\begin{array}{ll}\text { final result } \\
\text { weight }\end{array}$ & weight & Sub-criterion & weight & criteria \\
\hline .135 & .298 & Weather & .282 & environmental condition \\
\hline .068 & .149 & air pollution & & \\
\hline .026 & .059 & appropriate natural landscape & & \\
\hline .134 & .296 & existence of water resources & & \\
\hline 030 & .066 & physical broadness & & \\
\hline .060 & .132 & Topography & & \\
\hline .017 & .171 & $\begin{array}{lll}\text { appropriate } & \text { distance } & \text { from } \\
\text { Tehram } & & \\
\end{array}$ & .145 & geographical position \\
\hline .014 & .142 & $\begin{array}{ll}\text { appropriate distance from } \\
\text { metropolitans }\end{array}$ & & \\
\hline .070 & .688 & not being boarder & & \\
\hline .184 & .678 & Earthquake & .384 & locating in less risky zones in terms of \\
\hline 054 & .200 & Flood & & natural disasters \\
\hline .033 & .121 & Typhoon & & \\
\hline .045 & .496 & communicative location & .093 & appropriate infrastructures and facilities \\
\hline 012 & .139 & Railway & & \\
\hline 011 & .122 & Airport & & \\
\hline 022 & .243 & ground transportation network & & \\
\hline .009 & .733 & history of being capital & .054 & cultural and social structures \\
\hline 026 & .267 & $\begin{array}{l}\text { having } \\
\text { historical record }\end{array}$ & & \\
\hline .016 & .321 & Agriculture & .042 & economic condition \\
\hline 020 & .405 & Industry & & \\
\hline 014 & .274 & Services & & \\
\hline
\end{tabular}

(source: calculation of authors)

According to table 3, obtained results regarding evaluation of experts are as follow:

-Criterion of environmental condition status: weather with weight 0.298 , criterion of geographical position: not being border with weight 0.688 , criterion of locating in less risky zone: earthquake with weight 0.678 , criterion of facilities and infrastructures: communicative position with weight 0.496 , criterion of social and cultural structure in terms of importance 0.27 , history of being capital and 0.73 historical record criterion of economic condition: industry with weight of 0.405 had the greatest weights and importance

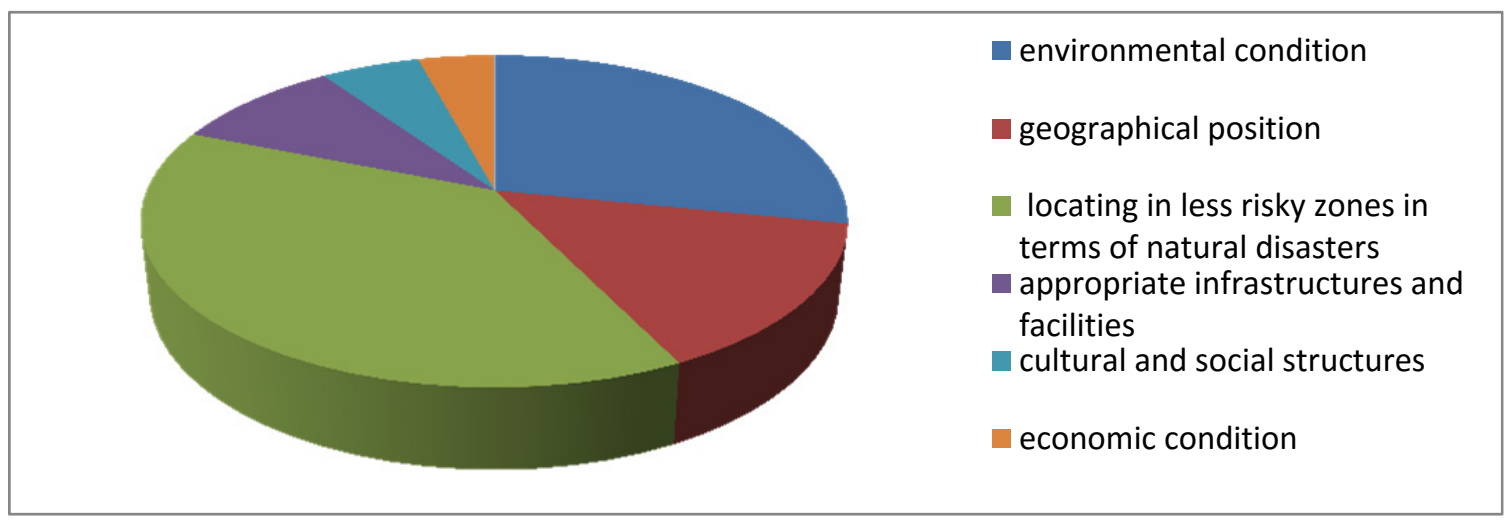

Figure 1. The final result of evaluating criteria by experts (source: authors) 
Finally, six indicators of environmental condition, locating in less risky zone, geographical position, appropriate infrastructures and facilities, social and cultural structures and economic condition acquired weights of 0.384 , $0.282,0.145,0.093,0.054,0.42$ respectively regarding importance and this data is shown in diagram 1 .

After examining opinions of experts and gaining final weights, features of each option was extracted, according to features and information of each option which were collected by sources and statistic lists. Each option was evaluated in comparison to criteria and sub-criteria of the research according to extracted features and results are as follow:

\subsection{Examining Criterion of Environmental Condition}

this criterion includes six criteria of weather (in order to examining criterion of weather, average value of air temperature, average of minimum temperature, average of maximum temperature and average of rainfall were examined and each option acquired a special score according to its features), air pollution, appropriate natural landscape, existence of water sources, physical broadness and topography. 19 studied options were evaluated in terms of these cases, weights of each option's sub-criteria and finally final weight in terms of environmental condition were obtained, and this data is shown in table 4:

Table 4. Weights of criteria and sub-criteria of environmental condition

\begin{tabular}{|c|c|c|c|c|c|c|c|c|c|c|c|c|c|c|c|}
\hline \multicolumn{16}{|c|}{ Environmental condition } \\
\hline 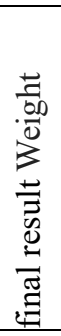 & 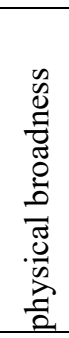 & 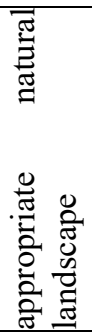 & 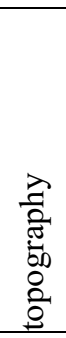 & 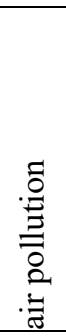 & 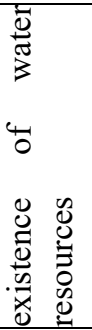 & $\begin{array}{l}\dot{D} \\
\bar{E} \\
\mathbb{E} \\
\vec{b}\end{array}$ & City Name & 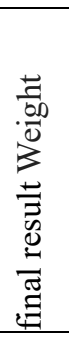 & 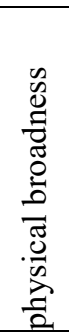 & 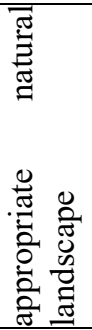 & 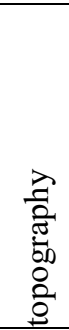 & 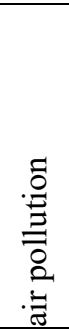 & 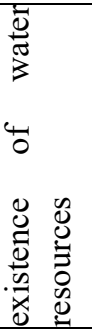 & 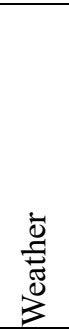 & City Name \\
\hline .094 & .156 & .075 & .064 & .102 & .119 & .088 & Fars & .033 & .033 & .028 & .064 & .016 & .021 & .032 & arak \\
\hline .077 & .014 & .075 & .064 & .016 & .119 & .088 & Qazvin & .042 & .156 & .075 & .064 & .016 & .021 & .032 & esfahan \\
\hline .024 & .014 & .028 & .021 & .016 & .021 & .032 & Qom & .057 & .014 & .075 & .064 & .041 & .021 & .088 & bojnourd \\
\hline .081 & .033 & .075 & .021 & .102 & .119 & .088 & dorodvaazna & .088 & .014 & .075 & .061 & .102 & .119 & .088 & boroujerd \\
\hline .041 & .156 & .013 & .064 & .041 & .021 & .032 & Myemeh & .026 & .014 & .013 & .064 & .016 & .021 & .014 & pardic \\
\hline .069 & .014 & .013 & .064 & .102 & .056 & .088 & Hashgerd & .054 & .014 & .028 & .023 & .102 & .021 & .088 & parand \\
\hline .033 & .014 & .075 & .021 & .041 & .056 & .014 & Hamadan & .077 & .014 & .075 & .064 & .016 & 119 & .088 & tabriz \\
\hline .037 & .156 & .075 & .021 & .041 & .021 & .032 & Yazd & .048 & .014 & .075 & .064 & .041 & .056 & .032 & zanjan \\
\hline .030 & .014 & .028 & .064 & .041 & .021 & .014 & Khomein & .039 & .096 & .028 & .064 & .041 & .021 & .032 & semnan \\
\hline & & & & & & & & .050 & .060 & .075 & .064 & .102 & .021 & .032 & shahrood \\
\hline
\end{tabular}

(sources: authors)

According to table 4, obtained results indicate that among examined options in terms of following cases, these cities are the most appropriate options:

Sub-criterion of weather: Bojnourd, Boroujerd, Parand with weight 0.088

Sub-criterion of air pollution: Boroujerd, Parand, Shahroud, Fars, Doroud Vazena, Hashtgerd with weight 0.102

Sub-criterion of topography: Arak, Isfahan, Bojnourd, Pardis, Tabriz, Zanjan, Semnan, Shahroud, Fars, Ghazvin, Meymeh, Hashtgerd and Khomein with weight 0.064

Sub-criterion of appropriate natural landscape: Isfahan, Bojnourd, Boroujerd, Tabriz, Zanjan, Shahroud, Fars, Qazvin, Doroud Vazena, Hamadan and Yazd with weight 0.075

Sub-criterion of existence of water resources: Boroujerd, Tabriz and Fars with weight 0.119

Sub-criterion of physical broadness: Isfahan, Fars, Meymeh and Yazd with weight 0.156 


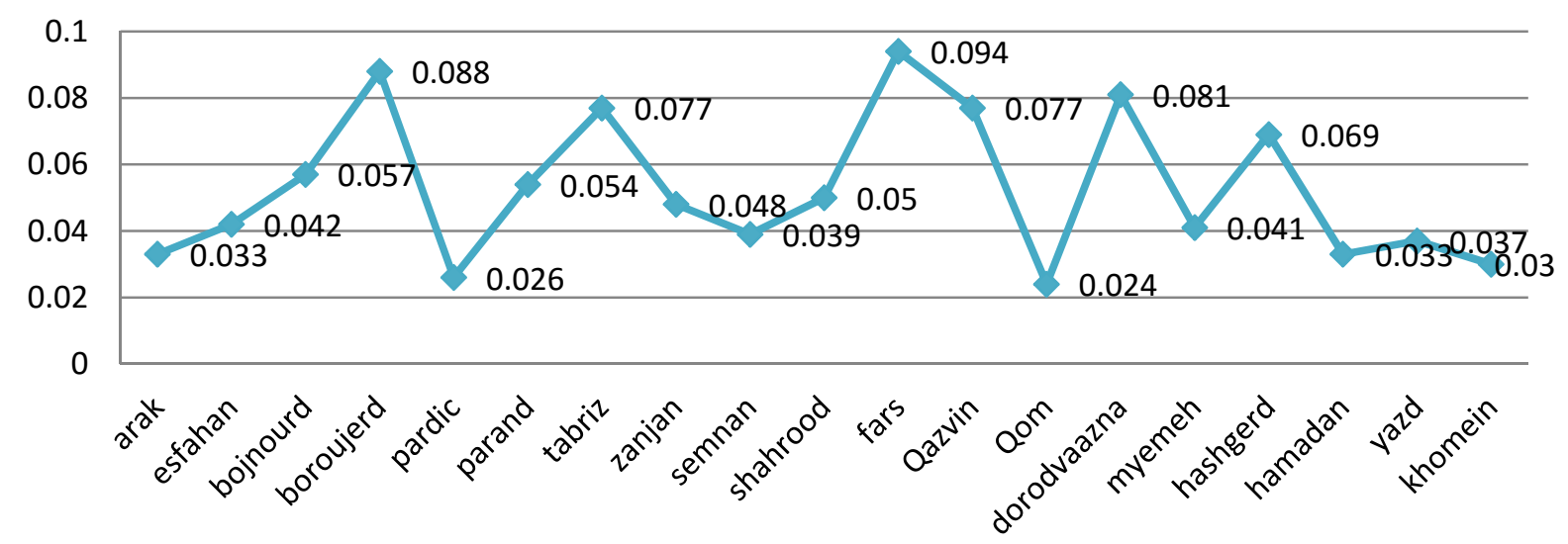

Figure 2. The final result from environmental condition (source: authors)

Finally, after general evaluation of options, Fars, Boroujerd and Doroud Vazena arethe most appropriate options among evaluated options in terms of general criterion of environmental condition with weights $0.094,0.088$ and 0.081 , respectively.

-Examining criterion of geographical position

In this stage, we examined 19 options in terms of geographical position including three sub-criteria of appropriate distance from Tehran, appropriate distance from metropolitans and not being broader. At the end, final scores of options were determined in terms of this criterion and were shown in table 5:

Table 5. Weights of criteria and sub-criteria of geographical position

\begin{tabular}{|c|c|c|c|c|c|c|c|c|c|}
\hline \multicolumn{10}{|c|}{ Geographical position } \\
\hline \multirow{3}{*}{ 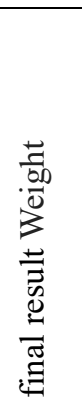 } & ह్๊ & $\stackrel{0}{0}$ & 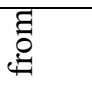 & \multirow{3}{*}{ City Name } & \multirow{3}{*}{ 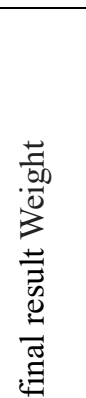 } & हี & हृ & $\stackrel{0}{0}$ & \multirow{3}{*}{ City Name } \\
\hline & 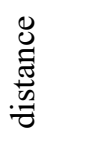 & 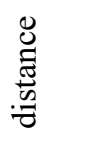 & 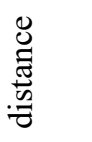 & & & 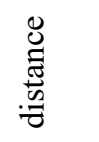 & 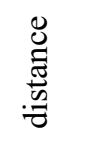 & 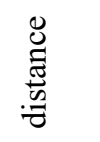 & \\
\hline & 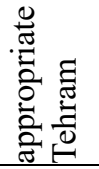 & 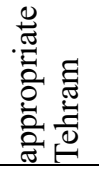 & 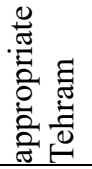 & & & 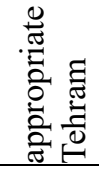 & 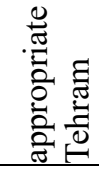 & 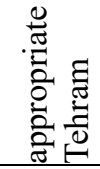 & \\
\hline .050 & .023 & .007 & .060 & fars & .060 & .070 & .049 & .060 & arak \\
\hline .066 & .070 & .113 & .060 & Qazvin & .057 & .070 & .021 & .060 & esfahan \\
\hline .066 & .070 & .113 & .060 & Qom & .057 & .070 & .021 & .060 & bojnourd \\
\hline .051 & .023 & .021 & .060 & dorodvaazna & .057 & 070 & .021 & .060 & boroujerd \\
\hline .060 & .070 & .049 & .060 & myemeh & .066 & .070 & .113 & .060 & pardic \\
\hline .066 & .070 & .113 & .060 & hashgerd & .060 & .023 & .113 & .060 & parand \\
\hline .017 & .023 & .049 & .012 & hamadan & .014 & .023 & .021 & .012 & tabriz \\
\hline .050 & .023 & .011 & .060 & yazd & .025 & .023 & .050 & .022 & zanjan \\
\hline \multirow[t]{2}{*}{.060} & .070 & .049 & .060 & khomein & .060 & .070 & .050 & .060 & semnan \\
\hline & & & & & .057 & .070 & .021 & .060 & shahrood \\
\hline
\end{tabular}

(source: authors) 
According to table 5. Among evaluated options in terms of following cases, the obtained results indicate that:

-Sub-criterion of appropriate distance from Tehram: Pardis, Parand, Qazvin, Qom and Hashtgerd with weight 0.13 are the most appropriate.

-Sub-criterion of appropriate distance from metropolitans: ARAK, Isfahan, Bojnourd, Boroujerd, Pardis, Shahroud, Qazvin, Qom, Meimeh, Hashtgerd and Khomein with weight 0.07 are the most appropriate.

-Sub-criterion of not being boarder: more distance from boarders of the country will results in more appropriate security condition.

According to obtained results among evaluated options, most of them are in good condition with weight 0.060 and options of Zanjan, Tabriz and Hamadan are the most inappropriate options with weights $0.022,0.012$ and 0.012 , respectively.

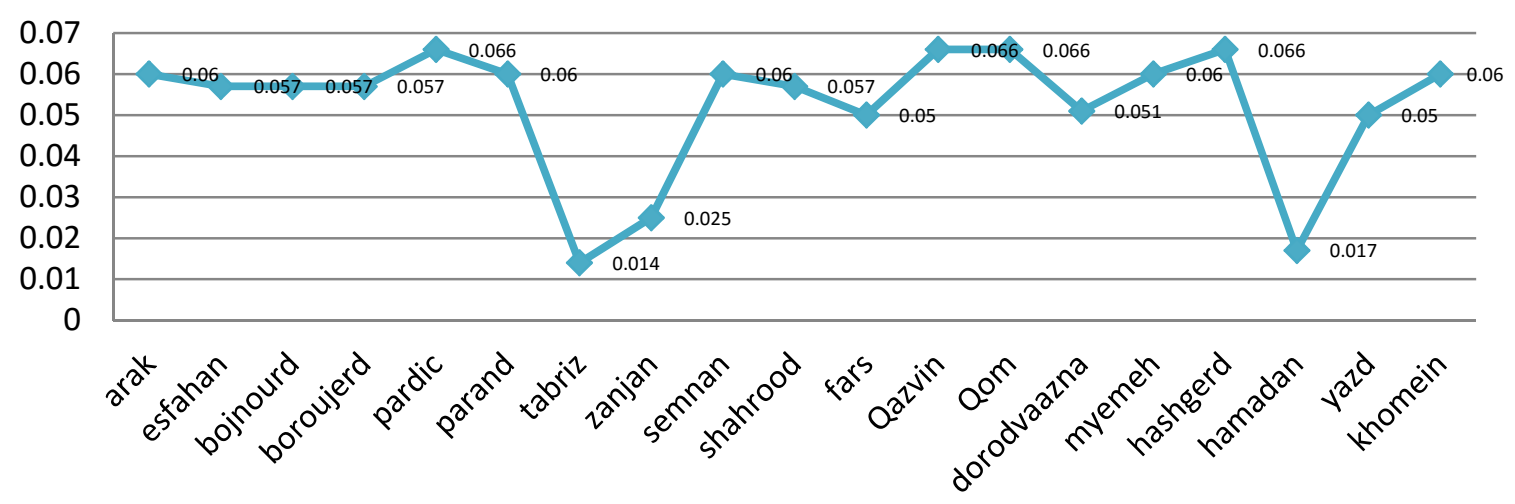

Figure 3. Final result of geographical position (source: authors)

After evaluating 19 options in terms of geographical position, results indicate that among evaluated options, Pardis, Qazvin, Qom and Hashtgerd are the most appropriate options with weight 0.066.

-Evaluating criterion of appropriate facilities and infrastructures:

-Criterion of facilities and infrastructures includes four sub-criteria of communicative location, railway, airport and ground transportation network and we evaluated 19 options regarding these criteria and we obtained results of table 6:

Table 6. Weights of criteria and sub-criteria of appropriate facilities and infrastructures

\begin{tabular}{|c|c|c|c|c|c|c|c|c|c|c|c|}
\hline \multicolumn{12}{|c|}{ Appropriate infrastructures and facilities } \\
\hline 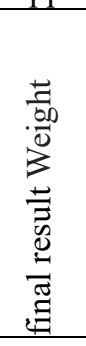 & 总 & $\frac{\vec{\pi}}{\frac{\pi}{\pi}}$ & 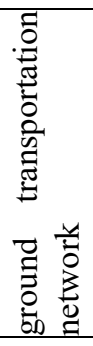 & 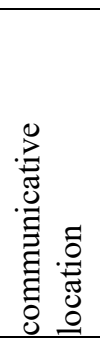 & City Name & 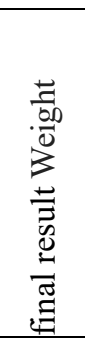 & 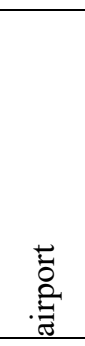 & 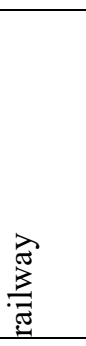 & 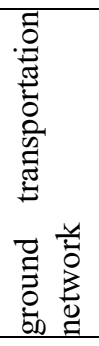 & 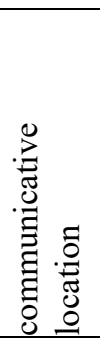 & $\begin{array}{l}\text { City } \\
\text { Name }\end{array}$ \\
\hline .083 & .124 & .122 & .110 & .065 & fars & .053 & .022 & .023 & .044 & .065 & arak \\
\hline .072 & .05 & 06 & .110 & 065 & 4 & .083 & 6 & 122 & .110 & 65 & \\
\hline .030 & .057 & .023 & .044 & .023 & Qom & 3 & .021 & .023 & .017 & .065 & Ird \\
\hline .048 & .021 & .023 & .017 & .065 & dorodvaazna & .0 & .021 & .023 & .017 & .065 & jerd \\
\hline .048 & .021 & .023 & .017 & .065 & & .0 & .021 & .023 & .044 & .065 & pardic \\
\hline .022 & .057 & .023 & .044 & .012 & hash & .053 & .021 & .023 & .044 & .065 & parand \\
\hline .048 & .021 & .023 & .017 & .065 & ham & .083 & .126 & .122 & .110 & .065 & tabriz \\
\hline .071 & .126 & .122 & .044 & .065 & yazd & .078 & .057 & .122 & .110 & .065 & zanjan \\
\hline
\end{tabular}




\begin{tabular}{llllllllllll}
\hline .015 & .021 & .023 & .017 & .012 & khomein & $\mathbf{. 0 3 3}$ & $\mathbf{. 0 5 7}$ & $\mathbf{. 0 6 0}$ & .044 & .023 & semnan \\
& & & & & & .027 & .021 & .023 & .044 & .023 & shahrood \\
\hline
\end{tabular}

(source: authors)

According to results of table $\mathbf{6}$ among evaluated options in terms of following cases, we have following results as the most appropriate options:

-Sub-criterion of communicative location: Arak, Isfahan, Bojnourd, Boroujerd, Pardis, Tabriz, Zanjan, Fars, Qazvin, Doroud Vazena, Meymeh, Hamadan and Yazd with weight 0.065

-Sub-criterion of ground transportation network: Isfahan, Tabriz, Zanjan, Fars and Qazvin with weight 0.110

-Sub-criterion of railway: Isfahan, Tabriz, Zanjan, Fars and Yazd with weight 0.060

-Sub-criterion of airport: Isfahan, Tabriz and Yazd with weight 0.126

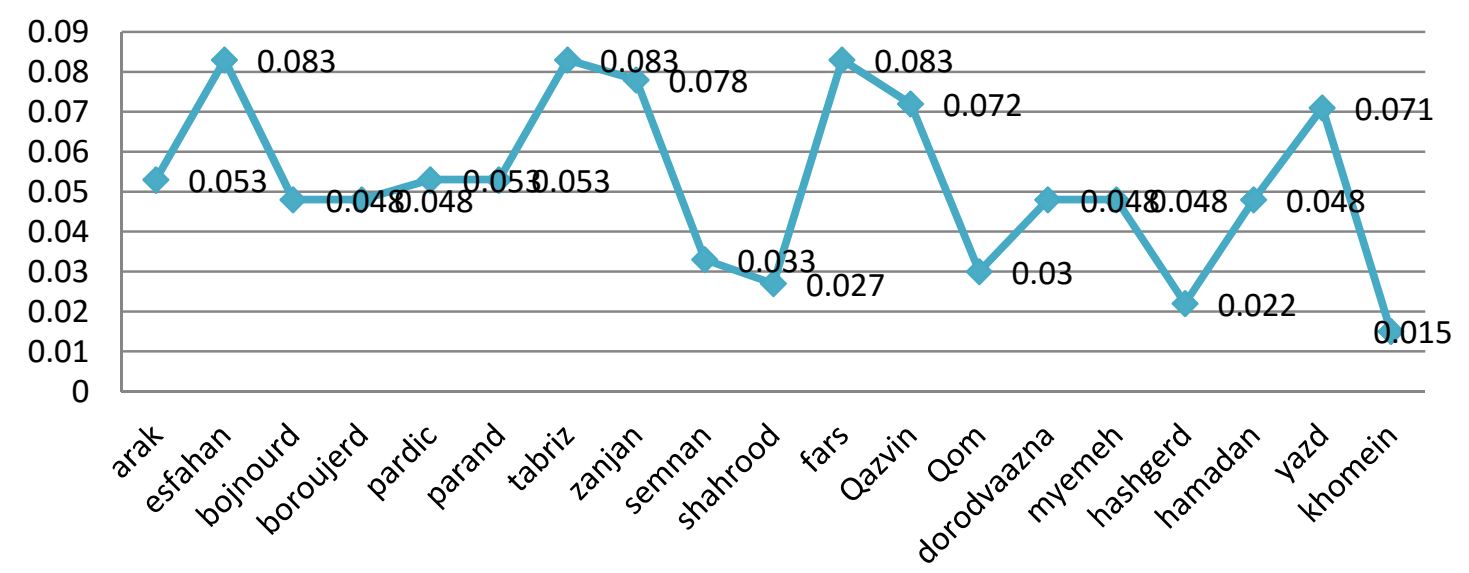

Figure 4. Final result of facilities and infrastructures (source: authors)

After evaluating 19 options in terms of appropriate facilities and infrastructures, obtained results show that among examined options, Isfahan, Tabriz and Fars are the best options with weight 0.083

-Evaluating criterion of social and cultural structure

Criterion of social and cultural structure include two sub-criteria of history of being capital and having historical record and 19 options were evaluated in terms of these criterion and sub-criteria and results of table 7 were obtained:

Table 7. Weights of criterion and sub-criteria of cultural and social

\begin{tabular}{|c|c|c|c|c|c|c|c|}
\hline \multicolumn{8}{|c|}{ cultural and social structures } \\
\hline 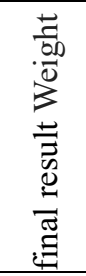 & 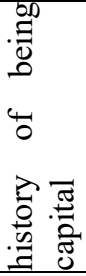 & 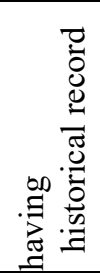 & City Name & 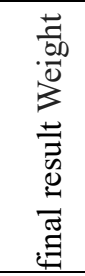 & 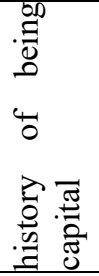 & 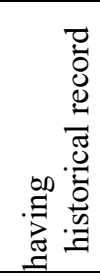 & City Name \\
\hline .070 & .103 & .063 & fars & .058 & .034 & .063 & arak \\
\hline $\begin{array}{l}.070 \\
.058 \\
.058 \\
.025\end{array}$ & $\begin{array}{l}.103 \\
.034 \\
.034 \\
.034\end{array}$ & $\begin{array}{l}.063 \\
.063 \\
.063 \\
.023\end{array}$ & $\begin{array}{l}\text { Qazvin } \\
\text { Qom } \\
\text { dorodvaazna } \\
\text { myemeh }\end{array}$ & $\begin{array}{l}.070 \\
.058 \\
.058 \\
.016\end{array}$ & $\begin{array}{l}.103 \\
.034 \\
.034 \\
.034\end{array}$ & $\begin{array}{l}.063 \\
.063 \\
.063 \\
.012\end{array}$ & $\begin{array}{l}\text { esfahan } \\
\text { bojnourd } \\
\text { boroujerd } \\
\text { pardic }\end{array}$ \\
\hline
\end{tabular}




\begin{tabular}{llllllll}
\hline $\mathbf{. 0 1 6}$ & $\mathbf{. 0 3 4}$ & $\mathbf{. 0 1 2}$ & hashgerd & $\mathbf{. 0 1 6}$ & $\mathbf{. 0 3 4}$ & $\mathbf{. 0 1 2}$ & parand \\
$\mathbf{. 0 7 0}$ & $\mathbf{. 1 0 3}$ & $\mathbf{. 0 6 3}$ & hamadan & $\mathbf{. 0 7 0}$ & $\mathbf{. 1 0 3}$ & $\mathbf{. 0 6 3}$ & tabriz \\
$\mathbf{. 0 5 8}$ & $\mathbf{. 0 3 4}$ & $\mathbf{. 0 6 3}$ & yazd & $\mathbf{. 0 5 8}$ & $\mathbf{. 0 3 4}$ & $\mathbf{. 0 6 3}$ & zanjan \\
$\mathbf{. 0 5 8}$ & $\mathbf{. 0 3 4}$ & $\mathbf{. 0 6 3}$ & khomein & $\mathbf{. 0 5 8}$ & $\mathbf{. 0 3 4}$ & $\mathbf{. 0 6 3}$ & semnan \\
& & & & $\mathbf{. 0 5 8}$ & $\mathbf{. 0 3 4}$ & $\mathbf{. 0 6 3}$ & shahrood \\
\hline
\end{tabular}

source: authors

According to table 7, the obtained results show that among evaluated options in terms of

-Sub-criterion of history of being capital: Isfahan, Tabriz, Fars, Qazvin and Hamadan are the most appropriate with weight 0.103

-Sub-criterion of having historical record: most cities have historical record with weight 0.063 and they are in a good condition.

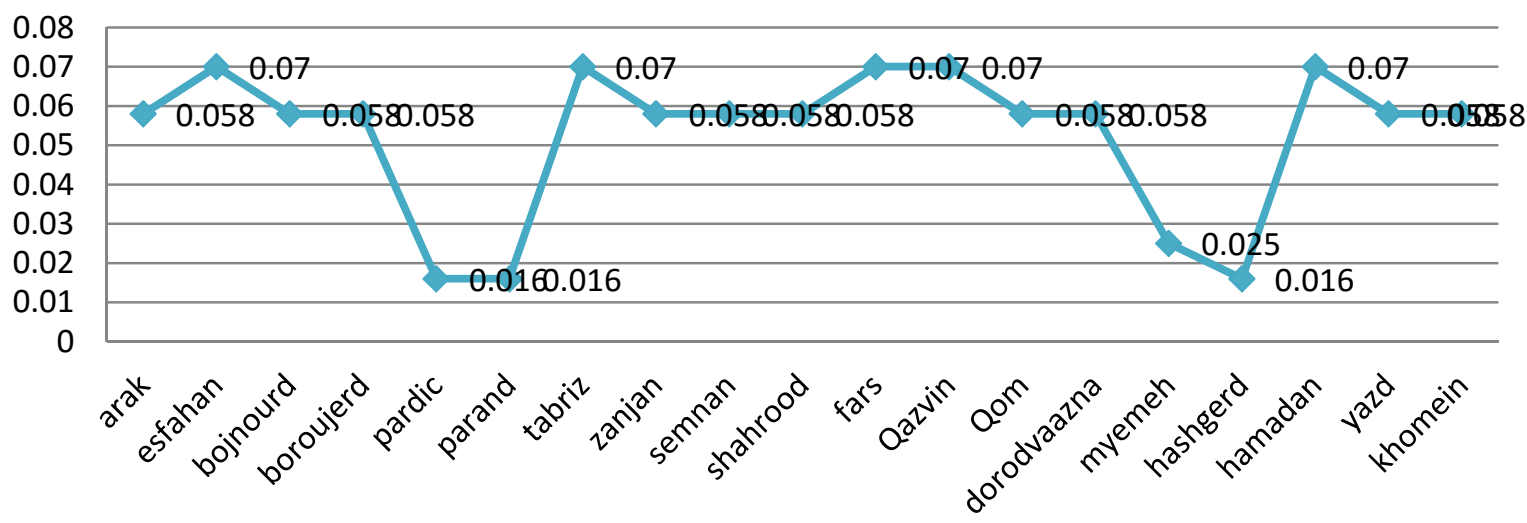

Figure 5. Final result of cultural and social structure (source: authors)

After final evaluation of criterion of cultural and social structure, the obtained results show that among evaluated options, Isfahan, Tabriz, Qazvin and Hamadan are the most appropriate options with weight 0.070 .

-Evaluating criterion of locating in less risky zones in terms of natural disasters:

Criterion of locating in less risky zones includes three sub-criteria of earthquake, flood and typhoon. And 19 options are evaluated based on obtained information and having record of natural disasters. Finally, we obtained results of table 8 :

Table 8. Weights of criterion and sub-criteria of locating in less risky zones

\begin{tabular}{|c|c|c|c|c|c|c|c|c|c|}
\hline \multicolumn{10}{|c|}{ locating in less risky zones in terms of natural disasters } \\
\hline 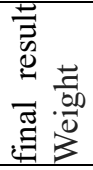 & 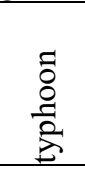 & $\begin{array}{l}8 \\
8 \\
\end{array}$ & 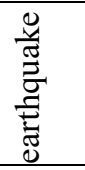 & City Name & 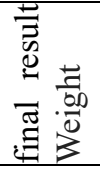 & 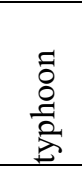 & $\begin{array}{l}\overline{8} \\
0 \\
\end{array}$ & 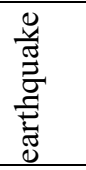 & City Name \\
\hline .029 & .032 & .029 & .028 & fars & .055 & .088 & .082 & .028 & arak \\
\hline .034 & .088 & .013 & .028 & Qazvin & .029 & .032 & .029 & .028 & esfahan \\
\hline .045 & .032 & .082 & .028 & Qom & .029 & .032 & 029 & .028 & bojnourd \\
\hline .081 & .088 & .082 & .079 & dorodvaazna & .039 & .088 & .029 & .028 & boroujerd \\
\hline .081 & .088 & .082 & .079 & myemeh & .115 & .032 & .082 & .161 & pardic \\
\hline .125 & .088 & .082 & .161 & hashgerd & .042 & .014 & .082 & .028 & parand \\
\hline .024 & .032 & .013 & .028 & hamadan & .026 & .014 & .029 & .028 & tabriz \\
\hline .042 & .014 & .082 & .028 & yazd & .039 & .088 & .029 & .028 & zanjan \\
\hline .055 & .088 & .082 & .028 & khomein & .056 & .032 & .029 & .079 & semnan \\
\hline
\end{tabular}


(source: authors)

\begin{tabular}{lllll}
.056 & .032 & .029 & .079 & shahrood \\
\hline
\end{tabular}

According to table 8, the obtained results show that among evaluated options in terms of -Sub-criterion of earthquake: Pardis and Hashtgerd with weight 0.161

-Sub-criterion of flood: Arak, Pardis, Doroud Vazena, Meimeh, Hashtgerd, Yazd and Khomein with weight 0.082 -Sub-criterion of typhoon: Arak, Zanjan, Qazvin, Doroud Vazena, Meymeh, Hashtgerd and Khomein with weight 0.088 are the most appropriate options.

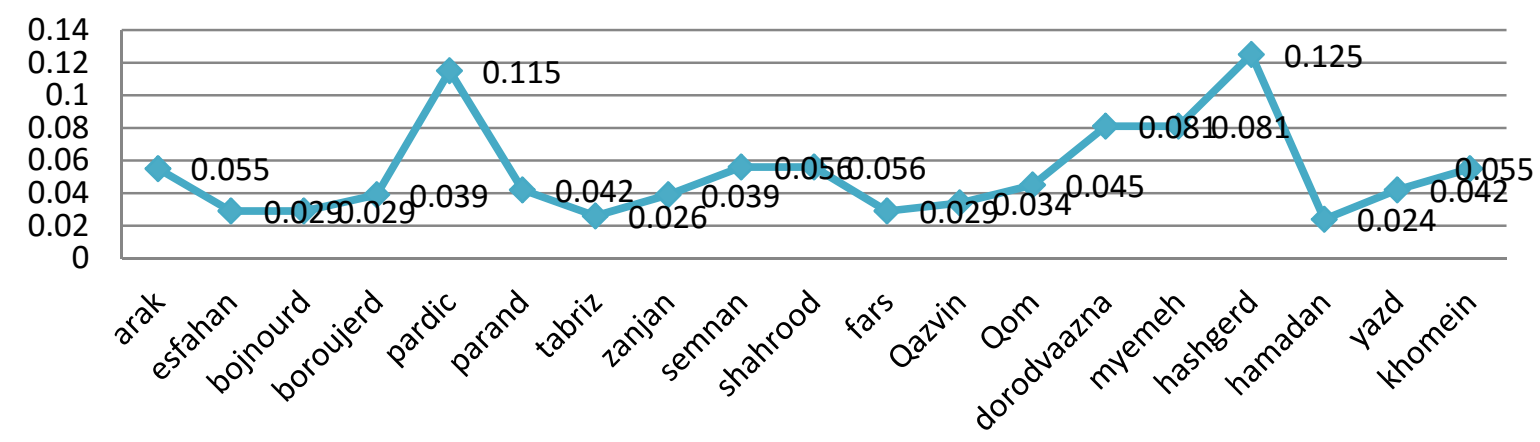

Figure 6. Final result of locating in less risky zones (source: authors)

The results in terms of locating in less risky zones indicate that among evaluated options, Hashtgerd, Pardis and Doroud Vazena are the most appropriate options with weights $0.125,0.115$ and 0.081 , respectively.

-Evaluating criterion of economical condition: this criterion includes three sub-criteria of agriculture, industry and services and 19 options are evaluated in terms of these criteria. Final results are shown in table $\mathbf{9}$.

Table 9. Weights of criterion and sub-criteria of economic condition

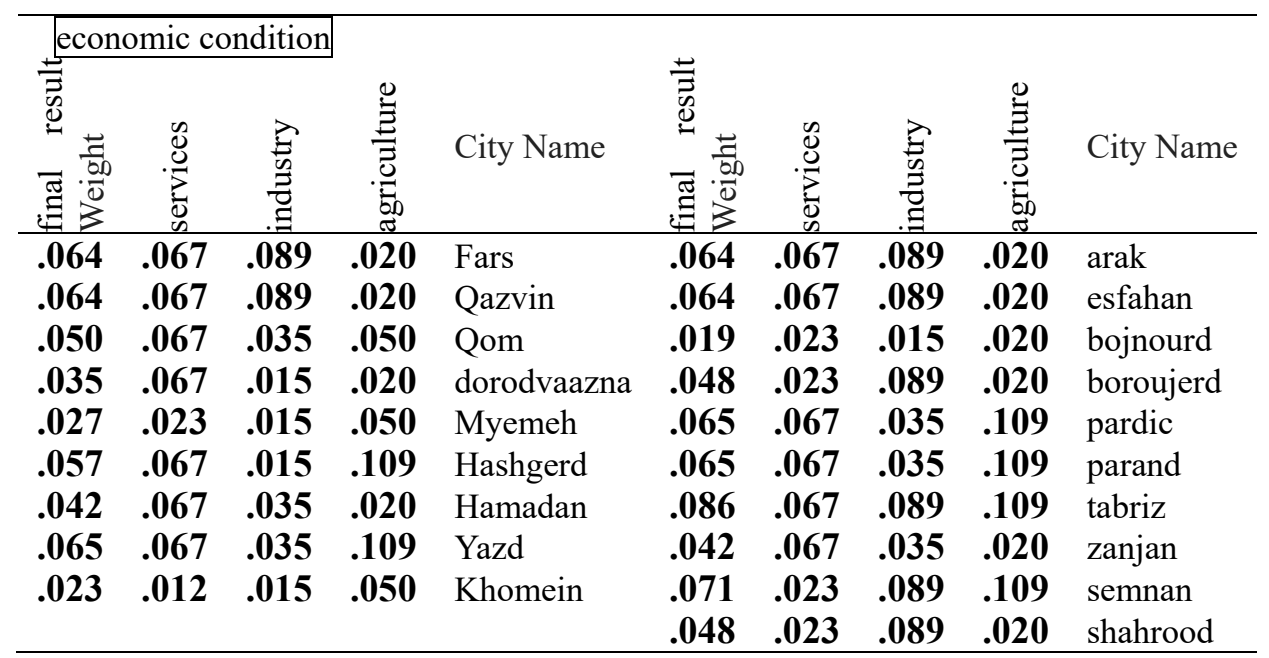

(source: authors)

According to table 9, the obtained results show that among evaluated results in terms of

-Sub-criterion of agriculture: Pardis, Parand, Tabriz, Semnan, Hashtgerd and Yazd with weight 0.109

-Sub-criterion of industry: Arak, Isfahan, Boroujerd, Tabriz, Semnan, Shahroud, Fars and Qazvin with weight 0.089 
-Sub-criterion of services: most cities except Bojnourd, Boroujerd, Semnan and Shahroud with weight 0.023 and Khomein with weight 0.012 are the most appropriate cities.

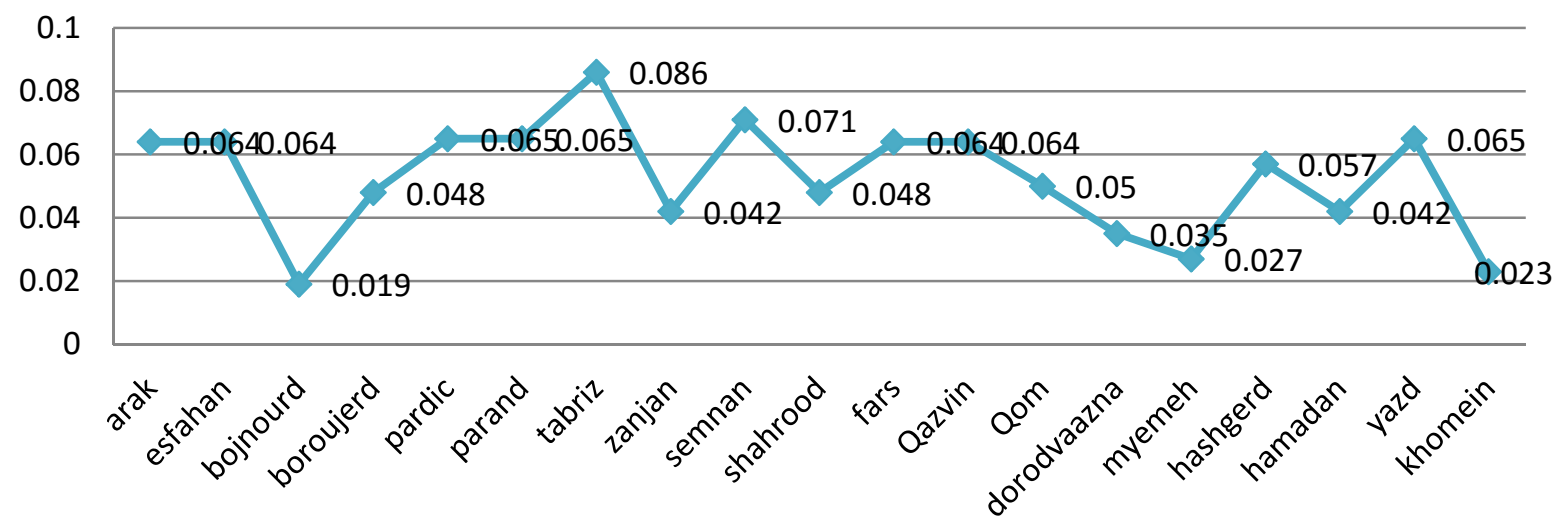

Figure 7. Final result of economic condition

The obtained results show that among evaluated options in terms of economic condition, Tabriz and Semnan are the most appropriate cities with weights 0.086 and 0.071 , respectively.

\subsection{The Final Evaluation of Options}

after evaluating options in terms of examined criteria and sub-criteria according to features of options, the final score of each option is obtained. the results indicate that according to table 10, among evaluated options, Hashtgerd, Doroud Vazena and Pardis are the most appropriate options for transferring the capital from Tehran.

Table 10. Final scores from evaluating cities

\begin{tabular}{lllll}
\hline Total scores & City Name & Total scores & City Name \\
\hline $\mathbf{. 0 5 0}$ & fars & $\mathbf{. 0 7 5}$ & arak \\
$\mathbf{. 0 5 0}$ & Qazvin & $\mathbf{. 0 6 8}$ & esfahan \\
$\mathbf{. 0 4 9}$ & Qom & $\mathbf{. 0 6 4}$ & bojnourd \\
$\mathbf{. 0 4 7}$ & dorodvaazna & $\mathbf{. 0 6 2}$ & boroujerd \\
$\mathbf{. 0 4 6}$ & myemeh & $\mathbf{. 0 6 1}$ & pardic \\
$\mathbf{. 0 4 4}$ & hashgerd & $\mathbf{. 0 5 9}$ & parand \\
$\mathbf{. 0 4 3}$ & hamadan & $\mathbf{. 0 5 6}$ & tabriz \\
$\mathbf{. 0 4 3}$ & yazd & $\mathbf{. 0 5 1}$ & zanjan \\
$\mathbf{. 0 3 2}$ & khomein & $\mathbf{. 0 5 0}$ & semnan \\
& & $\mathbf{. 0 5 0}$ & shahrood \\
\hline
\end{tabular}

(source: authors)

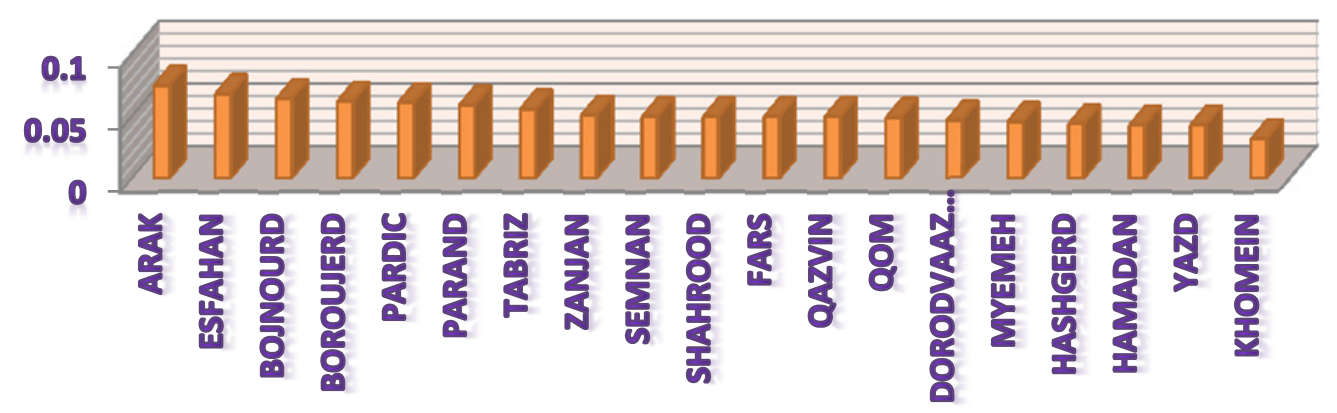

Figure 8. Final result from evaluating options (source: authors) 


\section{Conclusion and Recommendations}

Nowadays, the topic of transferring the capital is under more attraction due to several issues of Tehran city. The plan of transferring capital has high importance in different political, economical, management and executive dimensions. Therefore, it should be examined very carefully. The present research is conducted regarding choice of the most appropriate option for transferring the capital from Tehran and finally, following results are obtained:

According to opinions of experts and conducted examinations, six indicators of environmental condition, locating in less risky zones, geographical position, appropriate facilities and infrastructures, social and cultural structures and economic condition acquired weights of $0.384,0.282,0.145,0.093,0.054$ and 0.42 , respectively in order of importance.

Among evaluated options in terms of general criterion of environmental condition, Fars, Boroujerd and Doroud Vazena were the most appropriate cities with weights $0.094,0.088$ and 0.081 , respectively. In terms of geographical position among evaluated options, Pardis, Qazvin, Qom and Hashtgerd are the most appropriate cities with weight 0.066 . in terms of appropriate facilities and infrastructures, results showed that among evaluated options, Isfahan, Tabriz and Fars are the most appropriate cities with weight 0.083 . in terms of cultural and social structure, results showed that among evaluated options, Isfahan, Tabriz, Fars, Qazvin and Hamadan are the most appropriate cities with weight 0.070. in terms of locating in less risky zones, results showed that among evaluated options, Hashtgerd, Pardis and Doroud Vazena are the most appropriate cities with weights $0.125,0.115$ and 0.081 , respectively. Finally, in terms of economic condition, Tabriz and Semnan are the most appropriate cities with weights 0.086 and 0.071 , respectively.

After evaluating options in terms of examined criteria and sub-criteria according to features of each option, final score of each option is obtained and among evaluated options, Hashtgerd, Doroud Vazena and Pardis are the most appropriate cities for transferring the capital from Tehran with weights $0.075,0.068$ and 0.064 , respectively.

The obtained results in the present research are acquired regarding opinions of experts and features of each one of these cities. Generally, if we accept the results of this research, transferring the capital cannot solve the problem due to proximity of Hashtgerd and Pardis. Therefore, the capital should be transferred to a more distant place. It means next options with more distance from Tehran should be chosen or the problem should be solved essentially and it is a deep and full-aspect discussion on decentralization and various policies and using them; because if the capital is transferred to the next options, still existence of several concentrated structures makes the new place dysfunctional again. Therefore, it is recommended to deeply consider various strategies of decentralization in full-aspect, so we would stop seeing present problems of Tehran city in the new capital in future.

\section{References}

Ahamdi, Z., \& Gholizadeh, A. (2007). Determining effective factors in locating capitals in Iran. Journal of Geopolitics, 3(3).

Ahmadipour, Z., \& Gholizadeh, A. (2011). Political-geographical principles of locating capitals. Papli publication.

Ahmadipour, Z., Hafeznia, M., \& Gholizadeh, A. (2009). Determining effective factors in locating capital in Ancient Iran (according to its effects on creating Iranian identity). Political Science: National Studies, (39) (scientific-research).

Bagheri, B. M., Faskhoudi, A. A., \& Esfandiarpour, I. (2007). Zoning soil salinity in order to environmental usage of green space using AHP technique and statistical principles of land (In Kish Island). Research Journal of University of Isfahan, 22.

Behforouz, F. (2001). Dominant themes in human geography, Tehran, University of Tehran publication.

Campbell, S. (2003).The Enduring Importance of National Capital Cities in the Global Era. Urban and Regional Research Collaborative Working Paper URRC, 8(3).

Cohen, S. B. (1964). Geography and Politics in a Divided World. London : Methuen.

Dikshit, R. (1995). Political Geography: The Discipline and Its Dimension. New Delhi, Tata McGraw - Hill Publishing Company Limited.

Firouzi, M., \& Ghaffari, A. (2013). Transferring the capital: opponents and proponents. Geography: Development of Learning Geography, (104). 
Hafeznia, M, (2002). Political geography of Iran. (1Ed.), Tehran, Samt publication.

Hafeznia, M. (2002). Mutual relation of security and defense with land preparation. Proceedings of Land Preparation and Land Defense, (1Ed.), Imam Hussein University.

Islamic Council Parliament, Center of Research (2012). Expert opinion about: Plan of transferring the capital, 1(9), p. 238. ID: 228.

Mahdavi, B. (2009). getting ready for confronting earthquake; Etela'at newspaper, issue 2437.

Mepal, B.,Yadavm, O. P., \& Murat, A. (2010). A fuzzy-AHP approach to prioritization of CS attributes in target planning for automotive product development, Expert System With Applications.

Mirheidar, D. (1994). Principles of political geography. (3Ed.), Tehran, Samt publication.

Mirheidar, D. (2002). Principles of political geography. Tehran, Samt Publication.

Mohanty, W. K. M., Yanger, W., Sankar, K. N., \& Indrajit, P. (2007). First Order Seismic Microzonation of Delhi. India Using Geographic Information System ( GIS), Natural Hazards, 40, 245 -260.

Nobari, N., \& Rahimi, M. (2009). An analysis on transferring political capital of the country. Danesh-e-Shahr, 5.

Ozey, R. (1996). Asnn Ufkunda Turkiye. Istanbul: Marifet Yayinlari.

Pounds, N. J. G. (1963). Political Geography. New York: Mc Graw Hill Book Co.INC.

Sipahi, S., \& Mehpare, T. (2010). The analytic hierarchy process and analytic network process: An overview of applications. Management Decision, 48(5), 775 - 808.

Solnes, J. (2003). Environmental quality indexing of large industrial developnment alternatives using AHP. Environmental Impact Assessment Review, 23. Prevention and Management, 8(1), MCB University.

Son, Y. C. (2002). A GP -AHP method for solving group decisionmaking fuzzy AHP problems. Computer and Operations Research, (29), $1969-2001$.

Subhi, A., \& Al-Harbi, K. M(2001). Application of the AHP in project management. International Journal of Project Management, 19.

Taylor, P. J. (1989). Political Geography: World econom, nation-state, andlocality. New York, Longman Scintfic \& Technical, U. K.

Tehran will remain as Capital (2010). Hamshahri Newspaper, 5091, Saturday, 11 April.

Tong, Z. J., Zhang, J. Q., Lin, E., \& Peng, X. (2009). GIS-based risk assessment of grassland fire disaster in western in Jilin province,China. Stoch Environ Res Risk Assess, 23, 463 - 471.

Weigert, et. Al (1957). Principles of Political Geography. New York: APPLETONCENTURY-CROFTS, Jnc.

\section{Copyrights}

Copyright for this article is retained by the author(s), with first publication rights granted to the journal.

This is an open-access article distributed under the terms and conditions of the Creative Commons Attribution license (http://creativecommons.org/licenses/by/3.0/). 